\title{
Comparison of Growth Kinetics of Chaetoceros gracilis Isolated from Two Different Areas in the Aegean Sea (The Bay of Izmir and the Homa Lagoon)
}

\author{
${ }^{1}$ F. Sanem Sunlu, ${ }^{2}$ Banu Kutlu and ${ }^{1}$ H. Baha Buyukisik \\ ${ }^{1}$ Department of Hydrobiology, Faculty of Fisheries, Ege University, \\ 35100 Bornova, Izmir, Turkey \\ ${ }^{2}$ Faculty of Fisheries, Tunceli Universities, 62000, Tunceli, Turkey
}

\begin{abstract}
In this study, the species Chaetoceros gracilis was isolated from two different ecosystems (sea-lagoon) in the Bay of Izmir with very different physico-chemical environmental parameters. With the batch culture experiments carried out using the small diatom C. gracilis, it is aimed to determine the physiological properties of this species and also to form a basis for model studies by parameterizing its exponential growth rates, its nutrient limiting growth rates and the Michealis-Menten curves that indicate its dependence on nutrients. The fact that it is spread in a wide variety of areas from oligotrophic regions to eutrophic regions shows that this species environmental adaptation is quite interesting.
\end{abstract}

Key words: C. gracilis, diatom, growth kinetics, growth rate, half-saturation constant, parametersizing

\section{INTRODUCTION}

Of the phytoplankton groups, diatoms play a very important role in the primer production (Nelson et al., 1995; Treguer et al., 1995; Mann, 1999; Smetacek, 1999; Treguer and Pondaven, 2000). It is estimated that diatoms contributed to the primer production in the world by $20-25 \%$ because of their dominant roles in productive areas such as upwelling areas and continental shelves (Hendey, 1964). Therefore, it isn't surprising that there have been a lot of studies on diatoms among the other phytoplankton groups.

Of planktonic sea diatoms, Chaetoceros is the genus, along with Thalassiosira and Coscinodiscus which is spread over the greatest and widest area. It densely populates neritic areas and it is very common even in the high seas (Rines and Hargraves, 1988).

The usage of both some other types of the Chaetoceros genus and the C. gracilis genus (Artemia and Penaeus, some other crustacea species, some bivalve and mollusc species) that were used in the trial in breeding enhances the importance of studies in this field. Chaetoceros gracilis is commonly used as live feeds for all growth stages of bivalve mollusc (e.g., oystres, scallops, clams and mussels) for crustacean larvae and for zooplankton used as feed for larvae (Brown and Farmer, 1994; Brown and Miller, 1992; Lombardi and Wangersky, 1995, 1991; Saavedra and Voltolina, 1994a, b, 1995;
Parrish and Wangersky, 1990; Napolitano et al., 2007). The fact that phytoplankton cultures are used in kinetic studies and the individuals of the same species have the same features on constant environmental conditions (size, morphology, chemical composition have a distinctive quality in that they respond to the environmental conditions they are to be subjected in the same way. A lot of studies have been done on nutrient intake and kinetic studies for the abovementioned reasons.

The researches on kinetic studies have been done in a lot of variations. While some of them involved rivalry trials, others were realized in pure cultures. The main issues dealt with in these studies are light, heat and nutrients which are known to affect the growth of phytoplankton organisms primarily (Lopez-Ruiz et al., 1995; Levasseur et al., 1993; Thomas and Dodson, 1972; Izgoren-Sunlu and Buyukisik, 2006; Okumura et al., 2008; Fachini and Vasconcelos, 2006; Cleveland and Perry, 1987).

\section{Study area}

Izmir bay: The bay of Izmir is located in the Western part of Turkey and surrounded by a densely populated community. The bay is divided into the Inner, the Middle and the Outer Bay from the standpoint of topographical and hydrographical characteristics. The Inner bay occupies a small area $\left(57 \mathrm{~km}^{2}\right)$ and is shallow in depth (max. $15 \mathrm{~m})$ (Fig. 1).

Corresponding Author: F. Sanem Sunlu, Department of Hydrobiology, Faculty of Fisheries, Ege University, 35100 Bornova, Izmir, Turkey 


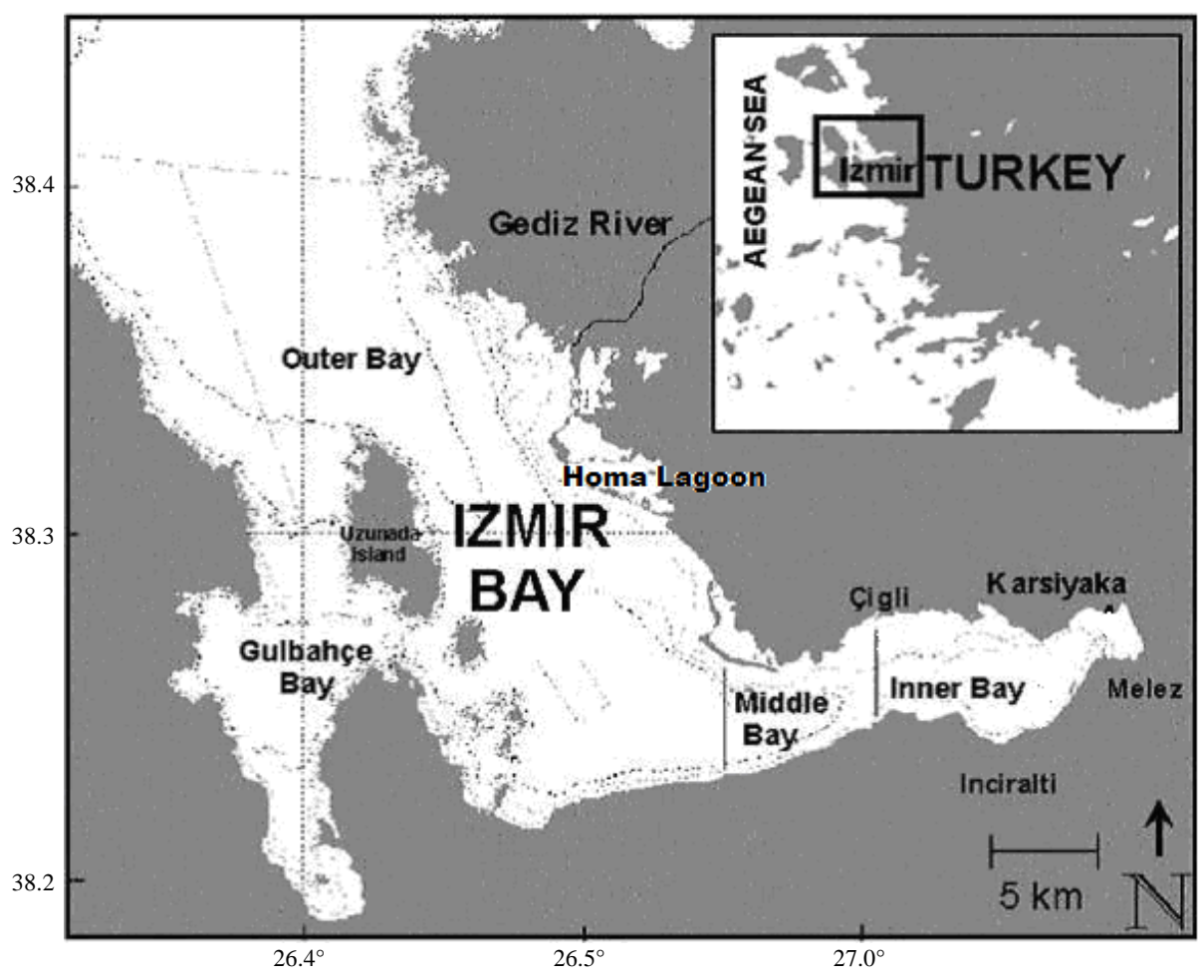

Fig. 1: Map of study area

Homa lagoon: This study was conducted in the Homa Lagoon area located at the outer part of Izmir Bay (northwest of Izmir, 38 $31^{\prime} 10^{\prime \prime}$ North latitude and $26^{\circ} 49^{\prime} 50^{\prime \prime}$ East longitude). This is an important region for commercial fisheries including bivalve (clam, mussel and oyster) located $35 \mathrm{~km}$ away from Izmir city in Aegean Sea. The various trials of clam culture were carried out inside the lagoon area (1800 ha acreage) at the near vicinity of the main lagoon entrance.

\section{MATERIALS AND METHODS}

For this study, C. gracilis Schutt was isolated with micropipette method described by Hoshaw and Rosowski (1973) from two different ecosystems (sea and lagoon) with very different physico-chemical environmental parameters. Isolates have been abbreviated as Clone 1 and Clone 2. Clone 1 represents Outer Bay isolates; Clone 2 represents Homa Lagoon isolates.

Experiments were conducted in a constant temperature room at $28^{\circ} \mathrm{C}$ and irradiated at $1300 \mathrm{ftCd}$ (foot-candle) by daylight fluorescent lambs. Cultures were maintained on a 12:12 light: dark cycle. For stock cultures and batch culture experiments, $\mathrm{f} / 2$ and $\mathrm{h} / 2$ mediums described by Guillard (1975) were used. The experiments were carried out in 1 L Pyrex bottles initially containing
$1 \mathrm{~L}$ of seawater. For the experiment, the concentrations of nutrients in $f / 2$ medium were changed and thus for every nutrient a different concentration was obtained. In the experiment groups, trace elements and vitamins were added to the seawater according to $\mathrm{f} / 2$ medium (Guillard, 1975).

Ammonium, phosphate and silicate were analysed by spectrophotometric method (Wood, 1975; Parsons et al., 1984) and nitrate by the copper-cadmium reduction method. All of the spectrophotometric analyses were carried out by using Bosch-Lomb Spectronic 21 UVD model spectrophotometer and also chlorophyll $\alpha$ analysis were performed using Turner 10-AU Model Fluorometer.

For the experiment groups, the nutrients were exposed, trace elements and vitamins were added to the seawater according to $\mathrm{f} / 2$ medium (Guillard, 1975). The studies were performed under non-limiting nutrient, light and temperature conditions except the nutrient exposed.

The specific growth rate was obtained from each growth curve calculating the following equation (Guillard, 1973):

$$
\mu=3.322 * \log \left(\mathrm{N}_{2} / \mathrm{N}_{1}\right) / \Delta \mathrm{t}
$$

where, $\mathrm{N}_{2}$ and $\mathrm{N}_{1}$ are the chlorophyll a concentration at the end $\left(\mathrm{t}_{2}\right)$ and beginning $\left(\mathrm{t}_{1}\right)$ of a period of time, $\Delta \mathrm{t}$ is the $t_{2}-t_{1}$. 
The rate of growth has been shown (Monod, 1942) to be related to the concentration of substrate in the medium by the following equation:

Where:

$$
\mu=\mu_{\max }\left(\mathrm{S} / \mathrm{K}_{\mathrm{s}}+\mathrm{S}\right)
$$

$\mu \quad=$ The specific growth rate

$\mu_{\max }=$ The maximum specific growth rate unlimited by low concentrations of substrate

$\mathrm{S}, \mathrm{K}_{\mathrm{s}}=$ (Half Saturation Constant) is the concentration that supports a rate equal to $\mu=\mu_{\max } / 2$

\section{RESULTS AND DISCUSSION}

Half saturation constant (Ks) stands for the ability of a phytoplankton to use low concentrations of a certain nutrient. Half saturation constant $(\mathrm{Ks})$ which is regarded as the affinity of phytoplankton in terms of nutrients in two regions is used as the index of species potential survival capacity in low density food concentrations (Smayda, 1997).

The Ks constants obtained when the growth rates $(\mu)$ of the phytoplankton cells cultured in a limited substrate concentration match up with the Monod Equation, reflects the species ability of nutrient intake on that conditions. That the obtained Ks value is low shows that the species is able to take in even the low concentrations of limited nutrients. So, the obtained value reflects an important feature of the sea plankton. Besides, it can change in sea phytoplankton depending on various factors (Sunlu and Buyukisik, 2006). Eppley et al. (1969a, b) reported that this constant was related to some factors depending on the $\mathrm{Ks}$ values determined for the phytoplankton species. These are:

- The phytoplankton organisms which have high (or low) Ks values for nitrate usually have high (or low) Ks values for ammonium as well

- Ks values increases in proportion with cell size

- Ks values for oceanic species tend to be lower than the bay species

- Fast reproducing species have lower Ks values than the more slowly growing species (Guillard and Kilham, 1977)

In this study, C. gracilis the different concentrations of nitrate, ammonium, phosphate and silicate for two clones of the C. gracilis species and their specific growth rates in these concentrations were drawn and the hyperbolic functions that describe the growth rates of both clones ( $\mathrm{S}$ versus $\mu$ values) under these conditions were obtained. In other words, the Monod equation was
Table 1: Half saturation constant and specific maximum growth rate values of C. gracilis from both isolates for different nutrients

\begin{tabular}{lcc}
\hline Chemicals & $\mathrm{Ks}\left(\mu \mathrm{mol} \mathrm{L}^{-1}\right)$ & $\mu_{\max }\left(\mathrm{day}^{-1}\right)$ \\
\hline Clone 1: Outer bay & & \\
$\mathrm{NO}_{3}$ & 0.98 & 1.53 \\
$\mathrm{NH}_{4}$ & 1.58 & 1.58 \\
$\mathrm{Si}$ & 0.67 & 1.78 \\
$\mathrm{PO}_{4}$ & 1.03 & 1.63 \\
Clone 2: Homa lagoon & & \\
$\mathrm{NO}_{3}$ & 2.26 & 1.59 \\
$\mathrm{NH}_{4}$ & 3.86 & 1.50 \\
$\mathrm{Si}$ & 0.14 & 1.44 \\
$\mathrm{PO}_{4}$ & 0.67 & 1.24 \\
\hline
\end{tabular}

applied by using the specific growth rates and thus the hyperbolic functions were obtained which characterize algal growth. These functions reflect the effect of the usage of the limited amount of $\mathrm{NO}_{3}{ }^{-}-\mathrm{N}_{,} \mathrm{NH}_{4}{ }^{+}-\mathrm{N}, \mathrm{PO}_{4}^{-3}-\mathrm{P}$, and $\mathrm{Si}$ concentrations on the growth rates.

The values obtained by comparing substrate concentrations with specific growth rates $(\mathrm{S} / \mu)$ are drawn versus Substrate concentrations (S) and the linear transformations of the hyperbolic functions that were described previously are obtained. Ks can be calculated from the point the regression line crosses the abscissa and $\mu$ max (maximum growth rate) can be calculated from the curve.

In this study the half saturation constant values and the maximum growth rates of both clones of $C$. gracilis are shown in Table 1. Great differences between the given values in these studies may be due to the differences of clones.

Nitrate: In this study, Clone 1 was exposed to ten different nitrate concentrations. As a result, the value of the half saturation constant was found to be $0.98 \mu \mathrm{mol} \mathrm{L}{ }^{-1}$ and $\mu_{\max }$ was found to be $1.53\left(\right.$ day $\left.^{-1}\right)$. Ten different nitrate concentrations were applied to Clone 2 . As a result, the value of the half saturation constant was found to be $2.26 \mu \mathrm{mol} \mathrm{L}{ }^{-1} \mu_{\max }$ nitrate concentrations were found to be $1.59\left(\right.$ day $\left.^{-1}\right)$. While the variation rate was $67 \%$ for Clone 1 , it was $77 \%$ for Clone 2 . The relationship of exponential growth rates vs. nitrate concentrations was shown as a Monod curve and transformation of the data ( $\mathrm{S} / \mu \mathrm{vs}$. S) to obtain linearized curve (Fig. 2a, b). The experimental points of the growth rates of Chaetoceros gracilis isolated from the Outer Bay of Izmir depending on $\mathrm{NO}_{3}{ }_{3}^{-} \mathrm{N}$ and the Michaelis-Menten curve that was made to match with these points are within $95 \%$ confidence interval $\left(\mathrm{R}^{2}=0.67, \mathrm{r}=0.82\right)$.

The experimental points of the growth rates of Chaetoceros gracilis isolated from the Homa Lagoon depending on $\mathrm{NO}_{3}{ }^{-} \mathrm{N}$ and the Michaelis-Menten curve that was made to match with these points are within $95 \%$ confidence interval $\left(\mathrm{R}^{2}=0.77, \mathrm{r}=0.88\right)$ (Fig. 2a, b). 

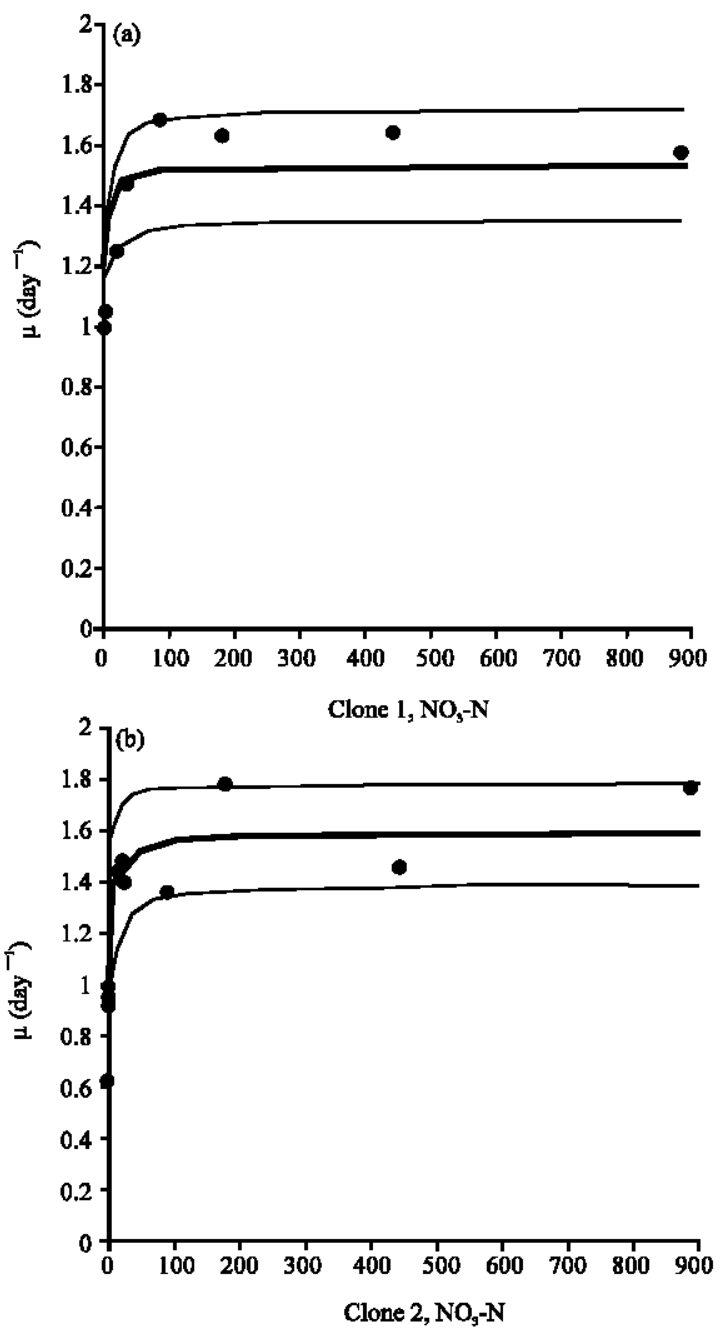

Fig. 2a, b: Specific growth rates of both clones as a function of nitrate concentration. The $S \mu^{-1}$ vs. S regression line was used to calculate $\mathrm{Ks}$ and $\mu \max$

Eppley and Thomas (1969) found Ks value as $0.2 \mu \mathrm{g} \mathrm{L}^{-1}$ under discontinuous culture conditions and at $21^{\circ} \mathrm{C}$ temperature for C. gracilis and the maximum growth rate as 3.2 day $^{-1}$. Eppley et al. $(1969 \mathrm{a}, \mathrm{b})$ found the $\mathrm{Ks}$ value of C. gracilis as $0.1-0.3 \mu \mathrm{g}$ at $\mathrm{L}^{-1}$ at $18^{\circ} \mathrm{C}$ in their trials of nutrient intake (Eppley, 1977).

These results are different from those of which are obtained in the trial. This may be due to two reasons: In these two studies, the areas where C. gracilis were isolated from have different characteristics. This causes a difference in their half saturation constants. Because according to Guillard (1973), the oceanic species (or clones) with similar sizes have lower Half saturation constants than bay species (Guillard and Kilham, 1977). Eppley and Thomas (1969) described the waters of the Tropical Pacific Ocean where they isolated C. gracilis as poor in nutrient. The species in the present study was isolated from the Outer Bay of Izmir which is rich in nutrient.

In addition, Eppley et al. (1969a, b) reports that Ks values for nitrate changes between $0.4-5.1 \mu \mathrm{g} \mathrm{L}-1$ in neritic regions. This interval for oceanic species changes between 0.1-0.7 $\mu \mathrm{g} \mathrm{L}^{-1}$. The other reason is the difference of conditions under which the two studies were conducted. The studies mentioned above were conducted at the temperatures of 18 and $21^{\circ} \mathrm{C}$ and this explains the differences in the values of Half saturation constant $(\mathrm{Ks})$ at $28^{\circ} \mathrm{C}$ and the maximum growth rate $(\mu \max )$.

Ammonium: Half-saturation constant was found to be $1.58 \mu \mathrm{mol} \mathrm{L}^{-1}$ for Clone 1 in the study in which twelve different ammonium concentrations were used and $\mu$ max was 1.58 day $^{-1}$. Half saturation constant was found to be $3.86 \mu \mathrm{mol} \mathrm{L}^{-1}$ for Clone 2 in the study in which twelve different ammonium concentrations were used and $\mu$ max was 1.50 day $^{-1}$. The variation growth rates for Clone 1 and Clone 2 are quite close; 83 and $85 \%$. The relationship of exponential growth rates ammonium concentrations was shown as a Monod curve and transformation of the data $(\mathrm{S} / \mu$ vs. S) to obtain linearized curve (Fig. 3a, b).

The experimental points of the growth rates of Chaetoceros gracilis isolated from the Outer Bay of Izmir depending on $\mathrm{NH}_{4}^{+}$and the Michaelis-Menten curve that was made to match with these points are within $95 \%$ confidence interval $\left(\mathrm{R}^{2}=0.8, \mathrm{r}=0.91\right)$. The experimental points of the growth rates of Chaetoceros gracilis isolated from the Homa Lagoon in Izmir depending on $\mathrm{NH}_{4}{ }^{+}$and the Michaelis-Menten curve that was made to match with these points are within $95 \%$ confidence interval $\left(R^{2}=0.85\right.$, $r=0.92$ ).

The results show that both clones prefer nitrate to ammonium when we look at the half-saturation constants and the responses C. gracilis isolated from the two areas gave to nitrate and ammonium, forms of $\mathrm{N}$ (Fig. 2a, b and $3 \mathrm{a}, \mathrm{b})$. In addition, the $\mathrm{Ks}$ value for Clone 1 isolated from the Outer Bay of Izmir which has oligotrophic conditions is lower than Clone 2 for two forms of $\mathrm{N}(0.98 \mu \mathrm{M}$ for nitrate, $1.58230 \mathrm{M}$ for ammonium). Because, Clone 2 was isolated from an area which is richer in nutrient than the Outer Bay. According to the literature, Ks values among the clones of the same species vary depending on many factors (Guillard and Kilham, 1977; Eppley et al. 1969a, b). These differences are due to the fact that the environment is nutrient-rich or nutrient-poor. Another description of half saturation constant $(\mathrm{Ks})$ is the increased intake. The $\mathrm{Ks}$ values of the species living in nutrient rich waters are always higher than those of the ones living in nutrient poor waters (Guillard and Kilham, 1977; Eppley et al., 


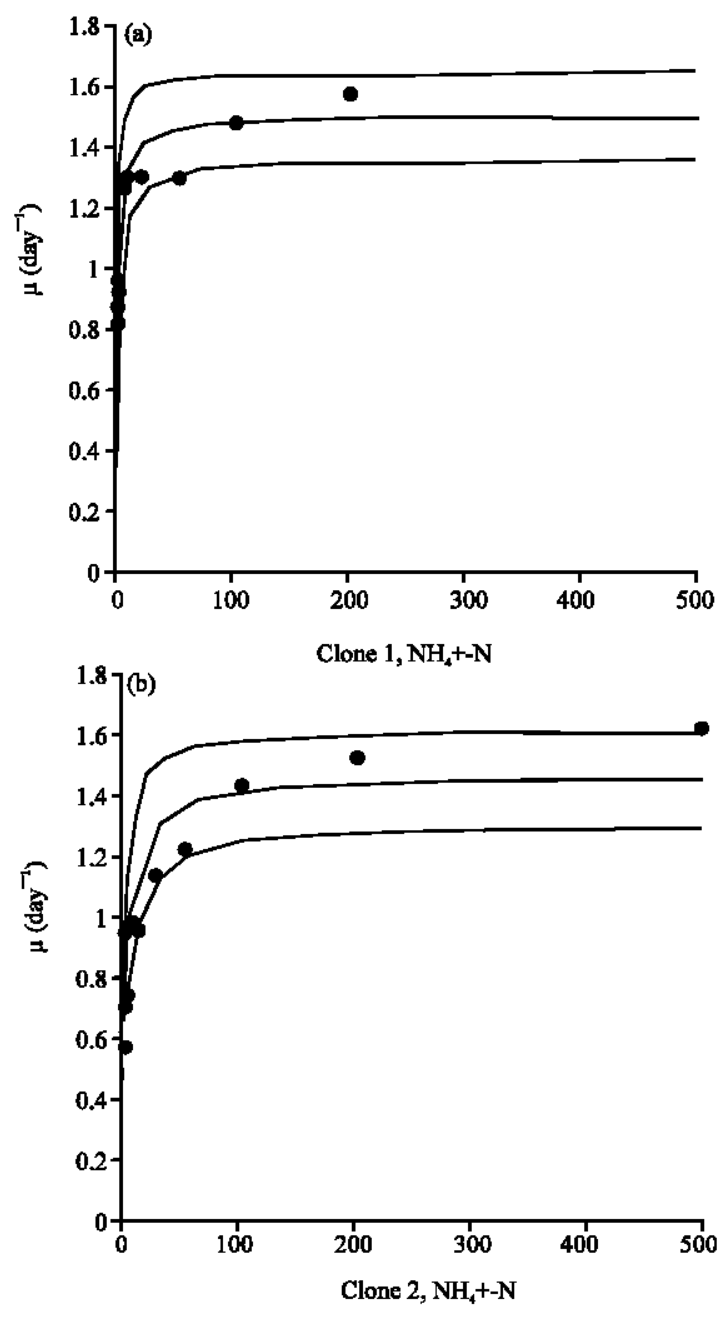

Fig. 3a, b: Specific growth rates of both clones as a function of ammonium concentration. The $\mathrm{S}$ $\mu^{-1}$ vs. S regression line was used to calculate $\mathrm{Ks}$ and $\mu \mathrm{max}$

1969a, b; Thomas and Dodson, 1975). Nitrogen restrictiveness in the large part of the year is worth paying attention to. This may originate from the contribution of waters of the Bay of Izmir as food source. Various researchers reported that the water column in the Bay of Izmir was nitrogen restrictive (Kontas et al., 2004; Kucuksezgin et al., 2006; TUBITAK, 2006; Bizsel et al., 2001).

Besides, another possibility is that compounds containing nitrogen go deeper in the bottom mud because of the shallow water column. According to the researches, the $\mathrm{Ks}$ values of neritic diatoms in eutrophic areas vary between 0.5 and $9.3 \mu \mathrm{g}$ at $\mathrm{NH}_{4}^{+}-\mathrm{N} \mathrm{L}^{-1}$ (Eppley et al., $1969 a$, b). According to these results, the values we obtained are within limits. Thomas and Dodson (1972) found the $\mathrm{Ks}$ value for $C$. gracilis isolated from the Tropical Pacific Ocean which is poor in nutrients to be $0.1 \mu \mathrm{M}$. The fact that $\mathrm{Ks}$ value of $C$. gracilis for nitrate is lower than that of ammonium shows that it can take in low concentrations of $\mathrm{NO}_{3}-\mathrm{N}$ in the medium. But it will prefer both of the nutrients under oligotrophic conditions.

Phosphate: Trials with ten different phosphate concentrations were done for Clone 1. Half-saturation constant was found to be $1.03 \mu \mathrm{mol} \mathrm{L}{ }^{-1}$ and the $\mu$ max value was 1.63 day $^{-1}$. The trials with the same concentrations were done for Clone 2 and the half saturation constant was found to be $0.67 \mu \mathrm{mol} \mathrm{L}{ }^{-1}$ and the $\mu \max$ value was 1.24 . While the variation growth rate for Clone 1 is $96 \%$, it was $62 \%$ for clone 2 . The variation growth rate for the Outer Bay was calculated to be 83 and $85 \%$ for the Homa Lagoon. While the $\mu$ max values for both areas are compatible, Half- saturation constant $(\mathrm{Ks})$ values for the Homa Lagoon were two times bigger than those of the Outer Bay. The relationship of exponential growth rates vs. phosphate concentrations was shown as a Monod curve and transformation of the data $(\mathrm{S} / \mu$ vs. $\mathrm{S})$ to obtain linearized curve (Fig. 4a, b).

The experimental points of the growth rates of Chaetoceros gracilis isolated from the Outer Bay of Izmir, depending on reactive phosphate and the MichaelisMenten curve that was matched with these points are within $95 \%$ confidence interval $\left(\mathrm{R}^{2}=0.96, \mathrm{r}=0.98\right)$. The experimental points of the growth rates of Chaetoceros gracilis isolated from the Homa Lagoon depending on reactive phosphate and the Michaelis-Menten curve that was matched with these points are within $95 \%$ confidence interval $\left(\mathrm{R}^{2}=0.62, \mathrm{r}=0.79\right)$.

Of the trial groups we exposed to the various concentrations of $\mathrm{PO}_{4}^{-3}$, when we look at the specific growth rates of C. gracilis in all concentrations, it can observe that it is affected by the determined levels of this nutrient. According to Liebig's minimum rule, low levels of phosphate lead to low rates of growth. This result is normal when we take into account that phosphate along with nitrogen is the most important nutrient in the growth of phytoplankton organisms.

When we look at the half-saturation constant values in terms of phosphate, the $\mathrm{Ks}$ value of phosphate, unlike nitrogen was higher for Clone 1 than it was for Clone 2 (1.03 and $0.67 \mu \mathrm{M}$, respectively). This is because the phosphate levels in the Outer Bay are higher than those in the Homa Lagoon. Thomas and Dodson (1975) calculated the $\mathrm{Ks}$ value for the same species as $0.12 \mu \mathrm{g}$ at $\mathrm{PO}_{4}{ }^{-3}-\mathrm{PL}^{-1}$. This may have two reasons.

Both studies were done in discontinuous culture but the temperatures of the studies are very different. Thomas and Dodson (1975) conducted their study at 

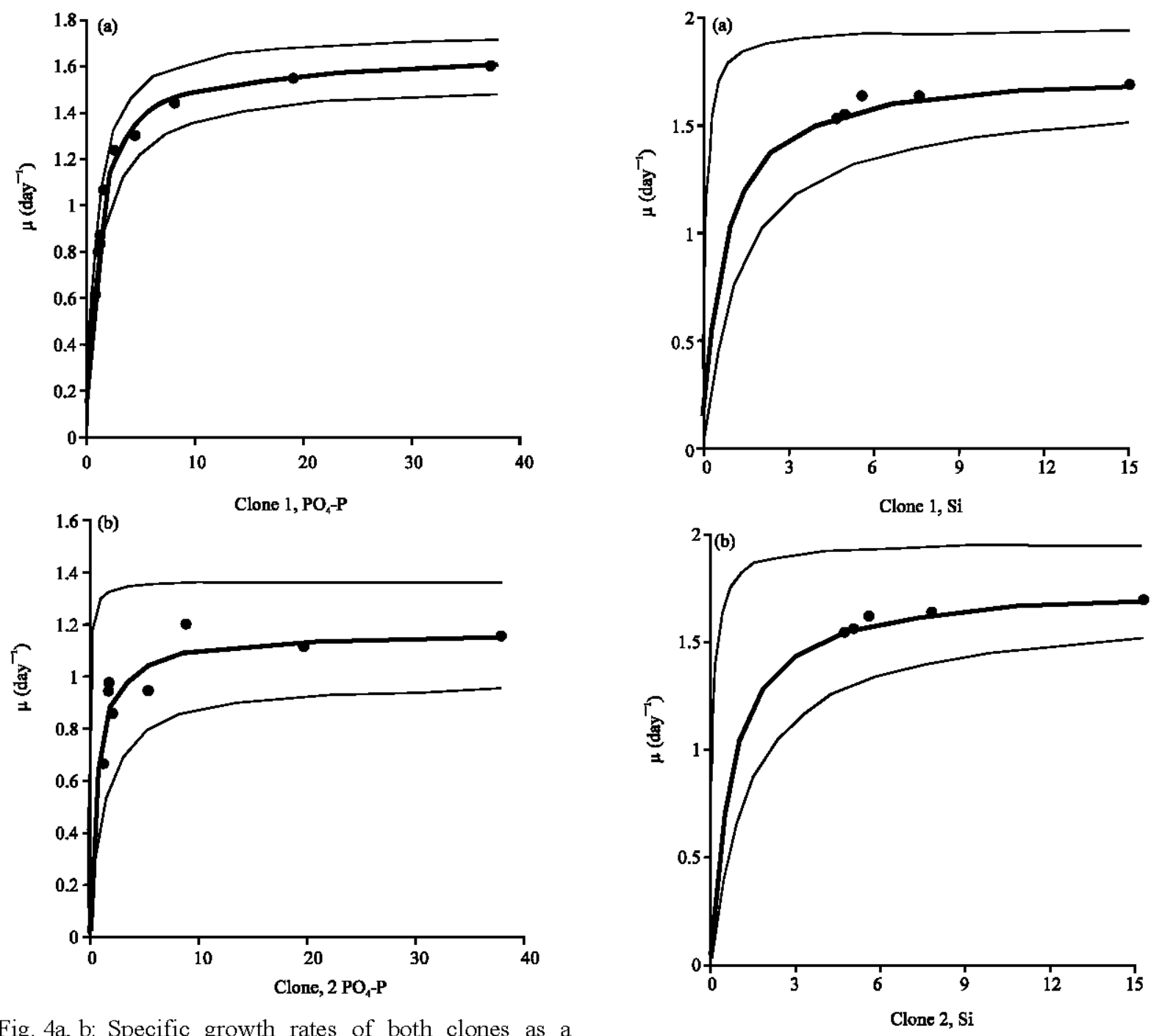

Fig. 4a, b: Specific growth rates of both clones as a function of phosphate concentration. The $\mathrm{S}$ $\mu^{-1}$ vs. S regression line was used to calculate $\mathrm{Ks}$ and $\mu$ max. Phosphate was found to be restrictive in the C. gracilis species isolated from the Bay of Izmir

$20^{\circ} \mathrm{C}$. The present study, on the other hand was conducted at $28^{\circ} \mathrm{C}$ which is the optimum temperature for this species. Temperature has an effect on half saturation constant values (Ks) as much as it does on maximum growth rates.

The areas C. gracilis were isolated from were different. The research materials were isolated from the Outer Bay of Izmir and the Homa Lagoon which are richer in nutrients than the Pacific waters but poorer in nutrients than the Inner Bay of Izmir.

Thomas and Dodson isolated the same species from the waters of the Pacific which they described as poor in nutrients.

Fig. 5a, b: Specific growth rates of both clones as a function of silicate concentration. The $\mathrm{S} \mu^{-1}$ vs. $\mathrm{S}$ regression line was used to calculate $\mathrm{Ks}$ and $\mu$ max

Silicate: Nitrogen and phosphate are, undoubtedly, the most important nutrients that inhibit phytoplankton growth in natural waters. However, silicate is important for diatom cell walls. The concentrations of these nutrients may change depending on the longitude and latitude of the sea waters, the distance from the shore, the depth etc. (Parsons et al., 1984). Ten different silicate concentrations were tried for Clone 1. As a result, the Half saturation constant was found to be $0.67 \mu \mathrm{mol} \mathrm{L}^{-1}$ and $\mu$ max was 1.78. In the study conducted likewise, Half saturation constant was found to be $0.14 \mu \mathrm{mol} \mathrm{L} \mathrm{L}^{-1}$ for Clone 2 and $\mu \max$ was $1.44\left(\right.$ day $\left.^{-1}\right)$. The relationship of exponential growth rates vs. nitrate concentrations was shown as a 
Monod curve and transformation of the data ( $\mathrm{S} \mu^{-1}$ vs. $\left.\mathrm{S}\right)$ to obtain linearised curve (Fig. 5a, b). In the study, the variation growth rates of both Clone 1 and Clone 2 was calculated as $83 \%$. The experimental points of the growth rates of Chaetoceros gracilis isolated from the Outer Bay of Izmir depending on silicate and the Michaelis-Menten curve that was matched with these points are within $95 \%$ confidence interval $\left(\mathrm{R}^{2}=0.67, \mathrm{r}=0.82\right)$. The experimental points of the growth rates of Chaetoceros gracilis, isolated from the Homa Lagoon depending on silicate and the Michaelis-Menten curve that was matched with these points are within $95 \%$ confidence interval $\left(\mathrm{R}^{2}=0.83\right.$, $\mathrm{r}=0.91$ ).

In another study, $\mathrm{Ks}$ value for the same species was found as $0.47 \mu \mathrm{g} \mathrm{Si} \mathrm{L}^{-1}$ (Thomas and Dodson, 1975). In the same study, maximum growth rate was determined as ( $\mu$ max) 3.21 day $^{-1}$. According to other studies on this subject, Ks values which are very different from each other were found. As a result while $\mu$ max values of the $C$. gracilis isolated from two different medium are approximate, their $\mathrm{Ks}$ values are different. This may be related to the water's nutrient value. That $\mu$ max values are approximate may be resulting from the fact that they are at the same latitudes in terms of light and temperature. That half saturation constants were different for two areas may be stemming from the fact that these isolated areas are very different in terms of physico-chemical features.

An interesting outcome of this study was that C. gracilis had approximate $\mu$ max values under the conditions of discontinuous culture in two areas where salinity was very different. This shows that the species is euryhalin. According to coastal and oceanic phytoplankton species, estuarine phytoplankton species tend to be euryhaline (Kennish, 1986).

\section{CONCLUSION}

As a result while $\mu$ max values of the $C$. gracilis isolated from two different areas were approximate and their Ks values were different.

\section{REFERENCES}

Bizsel, N., H.A. Benli, K.C. Bizsel and G. Metin, 2001. A synoptic study on the phosphate and phytoplankton relationship in the hypereutrophicated Izmir Bay (Aegean Sea). Turk. J. Eng. Environ. Sci., 25: 89-99.

Brown, M.R. and K.A. Miller, 1992. The ascorbic acid content of eleven species of microalgae used in marine culture. J. Applied Phycol., 4: 205-215.

Brown, R.M. and L.C. Farmer, 1994. Riboflavin content of six species of microBalgae used in mariculture. $\mathrm{J}$. Applied Phycol., 6: 61-65.
Cleveland, J.S. and M.J. Perry, 1987. Quantum yield, relative specific absorption and fluorescence in nitrogen-limited Chaetoceros gracilis. Mar. Biol., 94: 489-497.

Eppley, R.W. and W.H. Thomas, 1969. Comparison of half-saturation constants for growth and nitrate uptake of marine phytoplankton. J. Phycol., 5: 375-379.

Eppley, R.W., 1977. The Growth and Culture of Diatoms. In: The Biology of Diatoms, Werner, D. (Ed.). University of California Press, San Diego, pp: 498.

Eppley, R.W., J.L. Coatswarth and L. Solorzano, 1969a. Studies of nitrate reductase in marine phytoplankton. Limnol. Oceanogr., 14: 194-205.

Eppley, R.W., R.N. Rogers and J.J. McCarthy, $1969 \mathrm{~b}$. Half-saturation constants for uptake of nitrate and ammonium by marine phytoplankton. Limnol. Oceanogr., 14: 912-920.

Fachini, A. and S.D. Vasconcelos, 2006. Effects of zeolites on cultures of marine micro-algae. Environ. Sci. Pollut. Res., 13: 414-417.

Guillard, R.R.L. and P. Kilham, 1977. The Ecology of Marine Planktonic Diatoms. In: The Biology of Diatoms, Werner, D. (Ed.). University of California Press, California, pp: 498.

Guillard, R.R.L., 1973. Division Rates. In: Handbook of Phycological Methods: Culture Methods and Growth Measurements, Stein, J.R. (Ed.). Cambridge University Press, London, pp: 289-311.

Guillard, R.R.L., 1975. Culture of Phytoplankton for Feeding Marine Invertsbrates. In: Culture of Marine Invertebrate Animals, Smith, W.L. and M.H. Chanley (Eds.). Plenum Press, New York, USA., pp: 29-60.

Hendey, N.I., 1964. An introductory account of the smaller algae of British coastal waters. Part 5. Bacillariophyceae (Diatoms) London. N.M.S.O., pp: 317.

Hoshaw, R.V. and J.R. Rosowski, 1973. Methods for Microscopic Algae. In: Handbook of Phycological Methods-Culture Methods and Growth Measurements, Stein, J.R. (Ed.). Cambridge University Press, Cambridge, pp: 446.

Izgoren-Sunlu, F.S. and B. Buyukipik, 2006. Nutrient effects on the growth rates of marine diatom Chaetoceros gracilis schutt. E.U. J. Fish. Aquat. Sci., 23: $1-5$.

Kennish, M.J., 1986. Ecology of Estuaries Volume 2 Biological Aspect. CRC Press, Boca Raton, pp: 395.

Kontas, A., F. Kucuksezgin, O. Altay and E. Uluturhan, 2004. Monitoring of eutrophication and nutrient limitation in the Izmir Bay (Turkey) before and after wastewater treatment plant. Environ. Int., 29: 1057-1062. 
Kucuksezgin, F., A. Kontas, O. Altay, E. Uluturhan and E. Darilmaz, 2006. Assessment of marine pollution in Izmir Bay: Nutrient, heavy metal and total hydrocarbon concentrations. Environ. Int., 32: 41-51.

Levasseur, M., P.A. Thompson and P.J. Harrison, 1993. Physiological acclimation of marine phytoplankton to different nitrogen sources. J. Phycol., 29: 587-595.

Lombardi, A.T. and P.J. Wangersky, 1991. Influence of phosphorus and silicon on lipid class production by the marine diatom Chaetoceros gracilis grown in turbidostat cage cultures. Mar. Ecol. Prog. Ser., 77: 39-47.

Lombardi, A.T. and P.J. Wangersky, 1995. Particulate lipid classs composition of three marine phytoplankters Chaetoceros gracilis, Isochrysis galbana (Tahiti) and Dunaliella tertiolecta grown in batch culture. Hydrobiologia, 306: 1-6.

Lopez-Ruiz, J.L., G.R. Garcia, M. Soledad and F. Almeda, 1995. Marine microalgae culture: Chaetoceros gracilis with zeolitic product ZESTEC-56 and commercial fertilizer as a nutrient. Aquacult. Eng., 14: 367-372.

Mann, D.G., 1999. The species concept in diatoms. Phycologia, 38: 437-495.

Monod, J., 1942. La Croissance des Cultures Bacteriennes. Herman, Paris, pp: 210.

Napolitano, G.E., R.G. Ackman and W.M.N. Ratnayake, 2007. Fatty acid composition of three cultured algal species (Isochvysis galbana, Chaetoceros gracilis and Chaetoceros calcitrans) used as food for bivalve larvae. J. World Aquacult. Soc., 21: 122-130.

Nelson, D.M., P. Tréguer, M.A. Brzezinski, A. Leynaert and B. Quéguiner, 1995. Production and dissolution of biogenic silica in the ocean. Revised global estimates, comparison with regional data and relationship to biogenic sedimentation. Global Biogeochem. Cycles, 9: 359-372.

Okumura, A., R. Nagao, T. Suzuki, S. Yamagoe, M. Iwai, K. Nakazato and I. Enami, 2008. A novel protein in photosystem II of a diatom Chaetoceros gracilis is one of the extrinsic proteins located on lumenal side and directly associates with PSII core components. Biochimica Biophysica Acta, 1777: 1545-1551.

Parrish, C.C. and P.J. Wangersky, 1990. Growth and lipid class composition of the marine diatom, Chaetoceros gracilis, in laboratory and mass culture turbidostats. J. Plankton Res., 12: 1011-1021.
Parsons, R.T., M. Yoshiaki and G.M. Lalli, 1984. A Manual of Chemical and Biological Methods for Seawater Analysis. 1st Edn., Pergamon Press, Oxford, pp: 173.

Rines, J.E.B. and P.E. Hargraves, 1988. The Chaetoceros Ehrenberg (Bacillariophyceae) Flora of Narragansett Bay, Rhode Island, U.S.A. Bibliotheca Phycologica. Pergamon Press, Berlin, Stuttgart, pp: 188.

Saavedra, M.P.S. and D. Voltolina, 1994a. The chemical composition of Chaetoceros sp. (bacillariophceae) under different light conditions. Comp. Biochem. Physiol., 107: 39-44.

Saavedra, M.P.S. and D. Voltolina, 1994b. The effect of different photon fluence rates of blue-green light on the biomass quality of a coastal diatom in pilot scale, semicontinuous cultures. Scientia Martina, 60: $267-272$.

Saavedra, M.P.S. and D. Voltolina, 1995. The effect of different light quality on the food value of the diatom Chaetoceros sp. for Artemia franciscana. Kellogg Rivista Italiana Acquacoltura, 30: 135-138.

Smayda, T.J., 1997. Harmful blooms: Their ecophysiology and general relevance to phytoplankton blooms in the sea. Limnol. Oceanogr., 42: 1137-1153.

Smetacek, V., 1999. Diatoms and the ocean carbon cycle. Protist, 150: 25-32.

TUBITAK, 2006. The effects of Izmir big channel waste-water treatment project to the lower throphic level of Izmir Bay (Aegean Sea Turkey). TÜBITAK-CAYDAG Project No. 102Y116, Scientific Project Final Report, pp: 266.

Thomas, W.H. and A.N. Dodson, 1972. On nitrogen deficiency in tropical pacific oceanic phytoplankton. II. Photosynthetic and cellular characteristics of a chemostat-grown diatom. Limnol. Oceanogr., 17: 515-523.

Thomas, W.H. and A.N. Dodson, 1975. On silisic acid limitation of diatoms in near-surface waters of the eastern tropical Pacific Ocean. Deep Sea Res. Oceanographic Abstr., 22: 671-677.

Treguer, P. and P. Pondaven, 2000. Silica control of carbon dioxide. Nature, 406: 358-359.

Tréguer, P., D.M. Nelson, A.J. van Bennekom, D.J. de Master, A. Leynaert and B. Quéguiner, 1995. The silica balance in the world Ocean: A re estimate. Science, 268: 375-379.

Wood, R.D., 1975. Hydrobotanical Methods. University Park Press, Baltimor, pp: 173. 